\title{
ANALISIS PERBANDINGAN CAPM DENGAN TFMFF DALAM MENGESTIMASI RETURN SAHAM PADA JII PERIODE 2014-2016
}

\author{
Esi Fitriani Komara ${ }^{1}$, Eka Yulianti ${ }^{2}$ \\ Jurusan Manajemen Fakultas Ekonomi dan Bisnis ${ }^{1,2}$ \\ Universitas Jenderal Achmad Yani, Cimahi Indonesia \\ Esi.fk@lecture.unjani.ac.id ${ }^{1}$, yulianti_eka92@yahoo.com²
}

\begin{abstract}
In investing investors need to estimate returns, it is intended that the desired actual return is in accordance with the expected return. CAPM and TFMFF are models that can estimate stock returns. This study aims to determine whether (1) in the CAPM beta model as market risk affects the return. (2) on TFMFF excess return, firm size and BE / ME have an effect on return. As well as (3) CAPM or TFMFF which can estimate return better. The sample of this research is JII stocks for the period 2014-2016. Data analysis used is simple regression for CAPM and panel data regression for TFMFF. The results of this study state that, (1) beta does not affect return. (2) excess return and firm size affect return while BE / ME does not affect return. (3) TFMFF is better than CAPM in estimating the return of JII for the period 2014-2016.
\end{abstract}

Keywords: CAPM; TFMFF

\begin{abstract}
ABSTRAK
Dalam melakukan investasi investor perlu mengestimasi return, hal tersebut bertujuan agar return aktual yang diinginkan sesuai dengan return yang diharapkan. CAPM dan TFMFF merupakan model yang dapat mengestimasi return saham. Penelitian ini bertujuan untuk mengetahui apakah (1) pada model CAPM beta sebagai risiko pasar berperpengaruh terhadap return. (2) pada TFMFF excess return, firm size dan BE/ME berperpengaruh terhadap return.Serta (3) CAPM atau TFMFF yang dapat mengestimasi return lebih baik. Sampel penelitian ini adalah saham-saham JII periode 2014-2016. Analisis data yang digunakan adalah regresi sederhana untuk CAPM dan regresi data panel untuk TFMFF. Hasil penelitian ini menyatakan bahwa, (1) beta tidak berpengaruh terhadap return. (2) excess return dan firm size berpengaruh terhadap return sedangkan BE/ME tidak berpengaruh terhadap return.(3) TFMFF lebih baik dibandingkan CAPM dalam mengestimasi return JII periode 2014-2016.
\end{abstract}

Kata Kunci: $\boldsymbol{C A P M}$; TFMFF

\section{PENDAHULUAN}

Pada dasarnya investor mengharapkan suatu tingkat pengembalian (return) yang optimal dari investasi yang dilakukan. Akan tetapi, tingkat pengembalian yang diterima oleh investor tersebut tidak selalu sesuai dengan tingkat pengembalian yang diharapkan, artinya investor dihadapkan pada ketidakpastian. Sehingga investor dalam melakukan keputusan investasi, harus mempertimbangkan dua hal yang paling penting, yaitu return yang diharapkan dan risiko yang harus ditanggung. Risiko merupakan faktor yang tidak dapat dihindari karena jika investor mengharapkan tingkat return yang tinggi maka investor harus mampu menghadapi risiko yang tinggi pula. Sesuai dengan teori yang menyatakan bahwa high risk high return. Dengan demikian risiko merupakan faktor penting dalam keputusan investasi.

Manajerial, Vol. 18 No.1, Januari 2019, Hal - 41

http://ejournal.upi.edu/index.php/manajerial/ 
Mengestimasi return suatu saham merupakan hal yang penting dilakukan oleh para investor agar return aktual yang diinginkan sesuai dengan return yang diharapkan. Untuk mendukung hal tersebut, maka peneliti perlu melakukan pengembangan asset pricing model yang bertujuan untuk menemukan teknik terbaik dalam melakukan seleksi portofolio yang mampu memberikan pengembalian yang optimal (Prabawanti, 2010).

Penelitian mengenai asset pricing model terus berkembang dan semakin menarik untuk diteliti karena selalu menyisakan pro dan kontra berkaitan dengan model yang dapat menjelaskan perilaku variabel-variabel dalam investasi dengan lebih baik (Prabawanti, 2010).

Capital Asset Pricing Model (CAPM) merupakan model pengembangan dari model Markowitz (1952) yang mengasumsikan bahwa preferensi investor hanya didasarkan pada return ekspektasi dan risiko portofolio yang secara implisit menggangap bahwa investor memiliki fungsi utility yang sama (Prabawanti, 2010). Akan tetapi pada kenyataannya setiap investor memiliki fungsi utility yang berbeda sehingga setiap investor memiliki portofolio yang berbeda. Hal tersebut menyebabkan keraguan terhadap model Markowitz. Sehingga untuk mengatasi keraguan tersebut muncul lah model Capital Asset Pricing Model (CAPM). Capital Asset Pricing Model (CAPM), diperkenalkan oleh Sharpe (1964), Lintner (1965) dan Mossin (1996) merupakan model untuk menentukan harga suatu aset pada kondisi equilibrium (Komara, 2016). Model ini dapat menjelaskan bagaimana hubungan antara rata-rata return saham dengan faktor risiko. Dalam hal ini risiko yang diperhitungkan adalah risiko sistematis yang diwakili oleh beta, karena risiko yang tidak sistematis bisa dihilangkan dengan cara diversifikasi (Premananto, dkk 2004). Dengan kata lain, menurut model ini satu satunya faktor yang mempengaruhi return yang diharapkan adalah risiko pasar (beta) (Sudiyatno, dkk 2011). Banyak penelitian tentang validitas dari CAPM, misalnya penelitian yang dilakukan oleh Ismanto (2011), Isnurhadi (2014), Lemiyana (2015), Komara (2016), yang menyimpulkan bahwa beta atau resiko pasar dapat mempengaruhi return saham.

Akan tetapi, banyak peneliti yang meragukan konsep Capital Asset Pricing Model (CAPM). Salah satu yang menentang konsep Capital Asset Pricing Model (CAPM) adalah fama and french (1992), menurutnya return dapat dipengaruhi oleh banyak factor selain beta sebagai risiko pasar yaitu firm size yang diproksi oleh kapitalisasi pasar dan book to market ratio. Firm size berkorelasi negatif terhadap return dimana Semakin kecil kapitalisasi perusahaan maka return yang diperoleh akan semakin tinggi. Sedangkan book to market ratio (BM ratio) memiliki korelasi positif, jika book to market ratio tinggi maka akan memberikan peluang untuk mendaptkan return yang tinggi di masa yang akan datang karena saham mengalami undervalue. Sehingga Fama and French menyempurnakan model CAPM dengan memasukan dua factor tersebut sehingga muncul Fama and French Three Factor Model (fama and French dalam komara 2016). Peneliti yang mendukung Fama and French yaitu Komara (2016, Simangunsong, dkk (2014) dan Chui, at al (1998).

Securato, at all dan Bello (2008), melakukan penelitian tentang perbandingan CAPM dan three factors pricing model, hasilnya bahwa model yang terbaik dalam menjelaskan return adalah three factors pricing model dibandingkan CAPM. Sedangkan penelitian yang dilakukan oleh Porras (1998) dan Bartholdy, at all (2005), bahwa return tidak dipengaruhi oleh size dan book to market. Sebaliknya, beta berpengaruh terhadap return. Berdasarkan hasil penelitian diatas terlihat bahwa terdapat perbedaan hasil penelitian berkaitan dengan asset pricing model mana yang lebih baik dalam mengestimasi return. Tujuan yang ingin dicapai ingin mengetahui apakah (1) pada model CAPM beta sebagai risiko pasar berperpengaruh terhadap return. (2) pada TFMFF excess return, firm size dan BE/ME berperpengaruh terhadap return. Serta (3) CAPM atau TFMFF yang dapat mengestimasi return lebih baik.. Manfaat penilitian ini diharapkan dapat membantu investor dalam menentukan model yang terbaik untuk mengestimasi return.

Manajerial, Vol. 18 No.1, Januari 2019, Hal - 42

http://ejournal.upi.edu/index.php/manajerial/

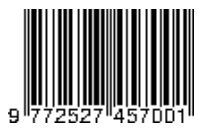




\section{KAJIAN PUSTAKA}

\section{Capital Asset Pricing Theory (CAPM)}

Secara terpisah, model ini pertama kali dikembangkan oleh Sharpe (1964), Lintner (1965) dan Mossin (1996). Sehingga model CAPM dinyatakan dengan rumus Lintner (1965), dan Sharpe (1964):

$$
\begin{aligned}
& \left.\mathrm{E}\left(\mathrm{R}_{\mathrm{i}}\right)=\mathrm{R}_{\mathrm{F}}+\beta_{\mathrm{i}}\left[(\mathrm{ERM})-\mathrm{R}_{\mathrm{F}}\right)\right] \\
& \text { Dimana: } \\
& \mathrm{E}(\mathrm{Ri})=\text { Ekspektasi return saham } \\
& \mathrm{Rf} \quad=\text { Return aset bebas risiko } \\
& \mathrm{Rm} \quad=\text { Return portofolio pasar } \\
& \beta_{\mathrm{i}} \quad=\text { Risiko sistematis dari saham } \mathrm{i}
\end{aligned}
$$

\section{Three Factor Model Fama and French}

Fama and French melakukan perluasan CAPM yang menyatakan bahwa dalam mengestiamsi return TFMFF lebih baik di bandingkan CAPM (Astuti, 2012). Menurut penelitian yang dilakukan oleh Fama (1992), bahwa tidak ada bukti hubungan antara beta dengan return. Kemudian tahun 1993 Fama menemukan bahwa faktor yang dominan dalam memprediksi return saham adalah size dan book to market. Oleh karena itu, Fama and French menggabungkan ketiga faktor tersebut. Sehingga muncul three Factor Model Fama and French yang dinyatakan dalam persamaan berikut:

$\mathrm{R}_{\mathrm{pt}}-\mathrm{R}_{\mathrm{ft}}=\alpha_{\mathrm{p}}+\beta_{1}\left(\mathrm{R}_{\mathrm{mt}}-\mathrm{R}_{\mathrm{ft}}\right)+\beta_{2} \mathrm{SMB}_{\mathrm{t}}+\beta_{3} \mathrm{HML}_{\mathrm{t}}+\mathrm{e}_{\mathrm{pt}}$

Dimana:

$$
\begin{array}{ll}
\mathrm{R}_{\mathrm{pt}} & \text { Rata-rata return bulanan } \\
& \text { portofolio } \\
= & \text { Riskfree rate bulanan } \\
\mathrm{R}_{\mathrm{ft}} & \text { Return pasar bulanan } \\
\mathrm{R}_{\mathrm{mt}} & \text { Excess return portofolio } \\
\mathrm{R}_{\mathrm{pt}}-\mathrm{R}_{\mathrm{ft}}= & \text { Market return } \\
\mathrm{R}_{\mathrm{mt}}-\mathrm{R}_{\mathrm{ft}}= & \text { Small Minus Big (proxy } \\
\mathrm{SMB} & \text { firm size) } \\
\mathrm{HML}= & \text { High Minus low (proxy } \\
& \text { BE/ME) } \\
\beta_{1} ; \beta_{2} ; \beta_{3}= & \text { Koefisien regresi } \\
\alpha_{\mathrm{p}}= & \text { Intercept dari regresi time } \\
& \text { Series } \\
\mathrm{e}_{\mathrm{pt}} & \text { Kesalahan pengganggu }
\end{array}
$$

\section{Studi Pendahuluan Mengenai Perbandingan CAPM dengan TFMFF dalam Mengestimasi Return Saham}

Penelitian yang berkaitan dengan estimasi return saham sudah banyak dilakukan. Akan tetapi hasil penelitiannya menunjukan hasil yang berbeda. Penelitian yang dilakukan oleh Bartholdy, at al (2005) dan Nofitasari, (2018), menyatakan bahwa Capital Asset Pricing Model (CAPM) dapat memberikan estimasi lebih baik dalam memprediksi dibandingkan dengan model Three Factor Fama and French (TFMFF). Sedangkan sebaliknya, hasil penelitian yang dilakukan oleh Prabawanti (2010), Securato, at al, Bello (2008), Porras (1998), Pitriyanti, dkk (2015), Rakhmawati (2015), dan Rizkiana, (2011), menyatakan bahwa model Tiga Faktor Fama dan French dapat memprediksi return saham yang lebih baik dibandingkan Capital Asset Pricing 
Model.

\section{METODE PENELITIAN}

Penelitian ini menggunakan metode penelitian kuantitatif, yaitu metode yang melakukan pengumpulan data berupa angka-angka yang kemudian dianalisis secara statistik. Metode penelitian kuantitatif yang digunakan adalah metode penelitian asosiatif dan komparatif. Metode asosiatif yang digunakan adalah penelitian kausalitas. Data penelitian ini menggunakan data sekunder yaitu dari website Bursa Efek Indonesia (www.idx.co.id), yahoo finance (www.finance.yahoo.com), dunia investasi (www.duniainvestasi.com), Bank Indonesia (www.bi.go.id), Sahamok (www.sahamok.com) dan britama (www.britama.com). Data sekunder yang dibutuhkan yaitu closing price saham perusahaan, suku bunga Sertifikat Bank Indonesia, Indeks Harga Saham Gabungan, Market Capitalization tiap perusahaan dan book equity tiap perusahaan. Data-data tersebut berupa data bulanan, kecuali market capitalization dan book equity berupa data tahunan dimana diasumsikan nilai market capitalization dan book equity sama selama satu tahun.

\section{Operasionalisasi Variabel}

Penelitian ini menggunakan variabel return saham (Ri), dan return pasar (Rm) untuk model Capital Asset Pricing Model (CAPM). Sedangkan Excess return, Market return, Firm Size, dan Book to Market Ratio (BE/ME) untuk Three Factor Fama and French model. Berdasarkan variabel tersebut peneliti menjabarkan ke dalam konsep variabel, indikator dan skala sebagai berikut:

Tabel 1. Operasionalisasi Variabel

\section{Capital Asset Pricing Model (CAPM)}

\begin{tabular}{|c|c|c|c|}
\hline Variabel & Konsep Variabel & Indikator & Skala \\
\hline \multicolumn{4}{|l|}{ Dependent } \\
\hline $\begin{array}{l}\text { Return Saham } \\
\text { (Ri) }\end{array}$ & $\begin{array}{l}\text { Pengembalian pendapatan atau hasil yang } \\
\text { diterima investor dari investasi yang } \\
\text { dilakuknnya, serta dijadikan sebagai } \\
\text { faktor yang memotivasi investor dalam } \\
\text { melakukan investasi }\end{array}$ & $\frac{\mathrm{P}_{\mathrm{t}}-\mathrm{P}_{\mathrm{t}-1}}{\mathrm{P}_{\mathrm{t}-1}}$ & Rasio \\
\hline \multicolumn{4}{|l|}{ Independent } \\
\hline $\begin{array}{l}\text { Return } \quad \text { Pasar } \\
(\mathrm{Rm})\end{array}$ & $\begin{array}{l}\text { Tingkat pengembalian atau hasil yang } \\
\text { diterima investor dari investasi pada } \\
\text { saham yang tercermin dari perubahan } \\
\text { harga periode tertentu. }\end{array}$ & $\frac{\mathrm{IHS} \mathrm{JII}_{\mathrm{t}}-\mathrm{IHS} \mathrm{JII}_{\mathrm{t}-1}}{\mathrm{IHS} \mathrm{JII} \mathrm{t}_{-1}}$ & Rasio \\
\hline \multicolumn{4}{|c|}{$\begin{array}{l}\text { Three Factor Fama and French model } \\
\text { Dependent }\end{array}$} \\
\hline Excess return & $\begin{array}{l}\text { Selisih antara keuntungan } \\
\text { saham bulanan dengan risk free rate }(\mathrm{RF}) \\
\text { bulanan. }\end{array}$ & $\begin{array}{l}\text { Excess return }=\mathrm{R}_{\mathrm{i}} \\
\text { perbulan }-\mathrm{R}_{\mathrm{f}} \\
\text { perbulan }\end{array}$ & Rasio \\
\hline \multicolumn{4}{|l|}{ Independent } \\
\hline Market return & $\begin{array}{l}\text { Selisih dari rata-rata return bulanan dari } \\
\text { seluruh saham dengan risk free rate } \\
\text { bulanan }\end{array}$ & $\begin{array}{l}\text { Market return }=\mathrm{Rm}- \\
\mathrm{Rf}\end{array}$ & Rasio \\
\hline Firm Size & $\begin{array}{l}\text { Nilai yang menunjukan ukuran } \\
\text { perusahaan yang dinyatakan dengan total } \\
\text { aktiva atau penjualan. Proxy firm size }\end{array}$ & $\mathrm{SMB}=\frac{1}{3}\left(\frac{S}{L}+\frac{S}{M}+\frac{S}{H}\right)-\frac{1}{3}\left(\frac{B}{L}+\frac{B}{M}\right.$ & Rasio \\
\hline
\end{tabular}

Manajerial, Vol. 18 No.1, Januari 2019, Hal - 44

http://ejournal.upi.edu/index.php/manajerial/ 
yang dipakai adalah SMB (Small Minus

Big)

Book to Market $\quad$ Rasio yang dapat digunakan sebagai

Ratio (BE/ME) indikator dalam mengukur kinerja

$\mathrm{HML}=\frac{1}{2}\left(\frac{S}{H}+\frac{B}{H}\right)-\frac{1}{2}\left(\frac{S}{L}+\right.$ Rasio perusahaan melalui harga pasarnya.

Proxy BE/ME yang dipakai adalah HML

(High Minus Low)

\section{Populasi dan Sampel Penelitian}

Populasi penelitian ini sebanyak 40 emiten yang tercatat di JII periode 2014-2016. penelitian ini menggunakan purposive sampling dalam menentukan sampel sehingga diperoleh sampel sebanyak 19 emiten. Berikut emiten yang dijadikan sampel.

Tabel 2. Sampel Penelitian

\begin{tabular}{cll}
\hline NO & KODE & \multicolumn{1}{c}{ NAMA EMITEN } \\
\hline 1 & AALI & Astra Agro Lestari Tbk \\
2 & ADRO & Adro Energy Tbk \\
3 & AKRA & AKR Corporindo Tbk \\
4 & ASII & Astra Internasional Tbk \\
5 & ASRI & Alam Sutera Realty Tbk \\
6 & BSDE & Bumi Serpong Damai Tbk \\
7 & ICBP & Indofood CBP Sukses Makmur Tbk \\
8 & INDF & Indofood Sukses Makmur Tbk \\
9 & INTP & Indocement Tunggal Prakarsa Tbk \\
10 & KLBF & Kalbe Farma Tbk \\
11 & LPKR & Lippo Karawaci Tbk \\
12 & LSIP & PP London Sumatera Plantation Tbk \\
13 & PGAS & Peusahaan Gas Negara (persero) Tbk \\
14 & SMGR & Semen Indonesia (Persero)Tbk \\
15 & SMRA & Summarecon Agung Tbk \\
16 & TLKM & Telekomunikasi Indonesia (Persero) Tbk \\
17 & UNTR & United Tractors Tbk \\
18 & UNVR & Unilever Indonesia Tbk \\
19 & WIKA & Wijaya Karya (Persero) Tbk \\
\hline
\end{tabular}

Sumber: www.idx.com

\section{Teknik Pengumpulan Data}

Teknik pengumpulan data penelitian ini adalah penelitian kepustakaan (liberary search) dan dokumentasi. Kepustakaan dilakukan dengan cara membaca buku dan karya ilmiah lainnya yang berkaitan dengan masalah yang diteliti. Sedangkan dokumentasi, digunakan untuk mengumpulkan data sekunder dari berbagai sumber.

\section{Analisis Data}

Penelitian ini menggunakan analisis data kuantitatif dengan alat bantu statistik yaitu program Eviews versi 9. Tahapan Analisis kuantitatif yang dimaksud adalah 1) Capital Asset Pricing Model (CAPM) yaitu a) menentukan data input berupa return saham individu (Ri), return pasar (Rm), dan Risk Free rate (Rf) bulanan periode 2014-2016. b) First-pass regression, tahap 
regresi pertama ini untuk menghasilkan nilai beta yang digunakan untuk proses regresi tahap kedua. c) Second pass regression, pada tahap ini dilakukan untuk mengetahui apakah market return berpengaruh terhadap return yang diharapkan. Adapun untuk hipotesis pertama dalam penelitian ini adalah sebagai berikut:

Ho : Market return berpengaruh terhadap return saham

$\mathrm{H} 1$ : Market return tidak berpengaruh terhadap return saham

Apabila probabilitas atau signifikansi lebih besar dari alpha, maka H0 diterima. 2) Three Factor Fama and French yaitu a) menentukan data input excess return, HML dan SMB periode 2014-2016. b) Pembentukan portofolio berdasarkan faktor size dan BE/ME. c) analisis regresi data panel, yang bertujuan untuk mengetahui apakah market return, firm size dan book to market ratio terhadap variable excess return. Adapun hipotesis kedua penelitian ini adalah:

Ho : Market return, firm size dan book to market ratio tidak berpengaruh terhadap return yang diharapkan

$\mathrm{H} 2$ : Market return, firm size dan book to market ratio berpengaruh terhadap return yang diharapkan

Apabila $P$-Value lebih besar dari alpha, maka H0 diterima. d) Uji asumsi klasik, yang terdiri dari uji heteroskedasitas, uji autokorelasi dan uji normalitas. e) Uji Koefisien Determinasi $\left(\mathrm{R}^{2}\right)$, penelitian ini mengacu kepada kriteria yang dilakukan oleh (Porras, 1998) dan (Bartholdy, at al 2005), dimana untuk penentuan model terbaik dari dua model asset pricing dapat menggunakan uji koefisien determinasi (Adjusted $\mathrm{R}^{2}$ ). Nilai adjusted $R$-Square adalah antara nol dan satu. Asset pricing model yang terbaik adalah model yang memiliki koefisien determinasi paling tinggi. Adapun hipotesis ketiga penelitian ini adalah:

Ho : Three Factors Pricing Model tidak lebih baik dalam menjelaskan return saham dibandingkan Capital Asset Pricing Model.

H3 : Three Factors Pricing Model lebih baik dalam menjelaskan return saham dibandingkan Capital Asset Pricing Model.

\section{HASIL PENELITIAN DAN PEMBAHASAN}

\section{Estimasi dan Hasil Perhitungan Regresi Sederhana Model CAPM}

Pada penelitian ini untuk menguji model CAPM dilakukan dua tahap regresi yaitu regresi tahap pertama untuk mengestimasi besarnya koefisien beta $(\beta)$. Adapun variabel dependen yang digunakan adalah return sekuritas dan vaiabel dependennya return pasar. Hasil regresi tahap pertama dapat dilihat pada tabel 5.6 diatas.

Kemudian regresi tahap kedua untuk membuktikan pengaruh antara beta $(\beta)$ sebagai risiko pasar terhadap excess return (Ri-Rf). Variabel dependen dari regresi tahap kedua ini adalah excess return ( $\mathrm{Ri}-\mathrm{Rf}$ ) dan variabel independennya adalah beta $(\beta)$. Berikut adalah hasil dari regresi tahap kedua.

Tabel 3. Hasil Perhitungan Regresi Sederhana Model CAPM

\begin{tabular}{l} 
Dependent Variable: RI_RF \\
\hline Method: Least Squares \\
Date: $12 / 11 / 18$ Time: $23: 06$ \\
Sample: 119 \\
Included observations: 19
\end{tabular}

Variable Coefficient Std. Error t-Statistic Prob. 


$\begin{array}{ccccc}\text { BETA } & -0.011731 & 0.015789 & -0.743004 & 0.4676 \\ \text { C } & -0.017491 & 0.016657 & -1.050094 & 0.3084\end{array}$

\begin{tabular}{lrlr} 
R-squared & 0.031452 & Mean dependent var & -0.029762 \\
Adjusted R-squared & -0.025521 & S.D. dependent var & 0.009353 \\
S.E. of regression & 0.009472 & Akaike info criterion & -6.381680 \\
Sum squared resid & 0.001525 & Schwarz criterion & -6.282265 \\
Log likelihood & 62.62596 & Hannan-Quinn criter. & -6.364855 \\
F-statistic & 0.552054 & Durbin-Watson stat & 1.616423 \\
Prob(F-statistic) & 0.467624 & & \\
\hline
\end{tabular}

Sumber: Diolah Kembali, 2018

Dilihat dari hasil regresi tahap kedua diatas. Dapat diketahui bahwa $p$-value dari beta sebesar $0,4676>$ dari $\alpha 0,05$ artinya beta tidak berpengaruh terhadap return pada level $5 \%$. Hal tersebut tidak sesuai dengan konsep yang dikembangkan oleh Sharpe (1964), Lintner (1965) dan Mossin (1996) yang menyatakan bahwa satu-satunya factor yang dapat mempengaruhi return adalah beta.

Akan tetapi hasil penelitian ini didukung oleh penelitian yang dilakukan oleh Fama and French (1992), Chui at al (1998), Hardianto dkk (2009),dan Simangunsong, dkk (2014), yang menyatakan bahwa beta sebagai indikator dari risiko pasar tidak mampu menjelaskan return saham.

Estimasi dan Hasil Perhitungan Regresi Data Panel Model Three Factor Fama and French

Alat analisis yang digunakan untuk menguji model Three Factor Fama and French dalam penelitian ini didasarkan analisis regresi data panel. Tahapan untuk mengestimasi model regresi diawali dengan model Common Effect, Fixed Effect, dan Random Effect. Berikut adalah ringkasan hasil estimasi dari ketiga model.

\section{Tabel 4. Hasil Perhitungan Regresi Data Panel}

\begin{tabular}{ccccccc}
\hline \multirow{2}{*}{ Variable } & \multicolumn{2}{c}{ Common Effect } & \multicolumn{2}{c}{ Fixed Effect } & \multicolumn{2}{c}{ Random Effect } \\
& Coef & Prob. & Coef & Prob. & Coef & Prob. \\
\hline X1 & 0.9821 & 0.0000 & 0.9821 & 0.0000 & 0.9821 & 0.0000 \\
X2 & 0.3221 & 0.0002 & 0.3221 & 0.0002 & 0.3221 & 0.0002 \\
X3 & 0.0890 & 0.1180 & 0.0889 & 0.1169 & 0.0889 & 0.1169 \\
C & 0.0030 & 0.5862 & 0.0030 & 0.5850 & 0.0030 & 0.6214 \\
R-squared & 0.7306 & 0.7386 & 0.7318 \\
Adjusted R-Squared & 0.7268 & 0.7285 & 0.7280 \\
F-statistic & 191.6115 & 73.0970 & 192.8148 \\
Prob(F-statistic) & 0.0000 & 0.0000 & 0.0000 \\
Durbin-Watson Stat & 2.2256 & 2.2937 & 2.2396 \\
\hline
\end{tabular}

Sumber: Diolah Kembali, 2018

Langkah selanjutnya dilakukan pengujian untuk memilih salah satu model yang dipilih dari ketiga model tersebut. Pengujian yang pertama yaitu Chow Test, pengujian ini berujuan untuk memilih model yang terbaik antara common effect dengan fixed effect, dengan hipotesis sebagai berikut:

H0: Common Effect

Ha: Fixed Effect 
Berikut ini hasil dari Chow Test .

Tabel 5. Hasil Chow Test

Redundant Fixed Effects Tests

Equation: Untitled

Test cross-section fixed effects

\begin{tabular}{lrrr} 
Effects Test & Statistic & d.f. & Prob. \\
\hline Cross-section F & 1.266277 & $(5,207)$ & 0.2798 \\
Cross-section Chi-square & 6.507639 & 5 & 0.2599
\end{tabular}

Sumber: Diolah Kembali, 2018

Dilihat tabel diatas, diketahui bahwa $\mathrm{P}$ value dari uji F dan Chi Square,sebesar 0,2798 dan 0,2599 lebih besar dari 5\% maka H0 diterima. Dengan demikian Common Effect merupakan model yang lebih baik dibandingkan dengan Fixed Effect. Sehingga tidak diperlukan pengujian selanjutnya yaitu Hausman Test.

Berdasarkan hasil regresi data panel diatas, diketahui bahwa model yang paling baik dalam mengestimasi regresi data panel adalah Common Effect. Sehingga hasil estimasi regresi data panel dengan model Common Effect dijadikan dasar untuk mengetahui apakah terdapat pengaruh dari market return, firm size dan BE/ME terhadap excess return baik secara parsial maupun simultan. Berikut adalah hasil estimasi regresi panel dengan model Common Effect.

Tabel 6. Hasil Estimasi Common Effect

Dependent Variable: Y

Method: Panel Least Squares

Date: 12/11/18 Time: 23:46

Sample: 2014M01 2016M12

Periods included: 36

Cross-sections included: 6

Total panel (balanced) observations: 216

\begin{tabular}{ccccc} 
Variable & Coefficient & Std. Error & t-Statistic & Prob. \\
\hline X1 & 0.982095 & 0.044387 & 22.12561 & 0.0000 \\
X2 & 0.322056 & 0.084215 & 3.824209 & 0.0002 \\
X3 & 0.088909 & 0.056645 & 1.569573 & 0.1180 \\
C & 0.003039 & 0.005573 & 0.545223 & 0.5862
\end{tabular}

R-squared

0.730566 Mean dependent var

$-0.023965$

Adjusted R-squared

0.726753

S.D. dependent var

0.143286

S.E. of regression

0.074900

Akaike info criterion

$-2.326989$

Sum squared resid

1.189312

Schwarz criterion

$-2.264484$

Log likelihood

255.3149

Hannan-Quinn criter.

$-2.301737$

F-statistic

191.6115

Durbin-Watson stat

2.225596

Prob(F-statistic)

0.000000

Sumber: Diolah Kembali, 2018

Manajerial, Vol. 18 No.1, Januari 2019, Hal - 48

http://ejournal.upi.edu/index.php/manajerial/ 


\section{Pengaruh Market Return (X1) Terhadap Excess Return (Y)}

Berdasarkan koefisien regresi dan P-Value dari market return pada tabel 5.14, dimana koefisien regresi sebesar 0,982095 dan P-Value sebesar $0.0000<0,05$ (H0 ditolak). Sehingga market return berpengaruh positif terhadap excess return dengan tingkat signifikansi sempurna. Koefisien sebesar 0,982095 menunjukan bahwa setiap peningkatan return market $1 \%$ akan meningkatkan excess return sekitar $0,98 \%$. Hasil penelitian ini mendukung penelitian Astuti (2012), Irawan, dkk (2011), Sudiyatno (2011), Nurafiyana (2010), Hardianto, dkk (2009), Malin, dkk (2004) serta mendukung penelitian yang dilakukan oleh Fama and French (1993) yang menyatakan bahwa market return memiliki pengaruh positif terhadap excess return, dimana semakin besar return market maka semakin besar return saham. Sebaliknya semakin kecil return market maka semakin kecil juga return saham.

\section{Pengaruh Firm Size (X2) Terhadap Excess Return (Y)}

Dilihat dari tabel 5.14 diketahui bahwa koefisien regresi dari firm size yang diproksi dengan nilai kapitalisasi pasar sebesar 0.322056 dan P-Value sebesar $0.0002<0,05$ (H0 ditolak). Sehingga Firm Size berpengaruh positif terhadap excess return dengan tingkat signifikansi sempurna. Koefisien sebesar 0.322056 menunjukan bahwa setiap peningkatan firm size $1 \%$ akan meningkatkan excess return sekitar $0,32 \%$. Kesimpulan penelitian ini sesuai dengan penelitian yang dilakukan oleh Astuti (2012), Irawan, dkk (2012) dan Nurafiyana (2010), yang menyatakan bahwa firm size memiliki pengaruh positif terhadap excess return, artinya semakin besar ukuran perusahaan maka excess return akan semakin besar. Hal tersebut kemungkinan disebabkan karena perusahaan dengan ukuran yang lebih besar memiliki akses yang lebih besar untuk mendapat sumber pendanaan dari berbagai sumber, sehingga untuk memperoleh pinjaman dari krediturpun akan lebih mudah karena perusahaan dengan ukuran besar memiliki probabilitas lebih besar untuk memenangkan persaingan atau bertahan dalam industri.

\section{Pengaruh Book to Market Ratio (X3) Terhadap Excess Return (Y)}

Dari tabel 5.14 diketahui bahwa excess return tidak diberpengaruhi oleh book to market ratio. Hal tersebut terlihat dari P-Value sebesar 0,1180>0,05 (H0 diterima) dan koefisien regresi sebesar 0,088909. Hasil penelitian ini tidak sesuai dengan penelitian yang dilakukan oleh Fama and French (1993). Akan tetapi mendukung penelitian yang dilakukan oleh Ismanto (2011), Fitriati (2010), Bartholdy, at all (2005), dan Porras (1998) yang menyatakan bahwa book to market value tidak mempengaruhi return.

\section{Pengujian Simultan}

Mencermati tabel 5.14, terlihat bahwa nilai Prob (F statistic) sebesar $0.0000<0,05$ (H0 ditolak). Maka dapat disimpulkan bahwa secara simultan ketiga variabel independen yaitu market return, firm size, dan book to market ratio berpengaruh terhadap variabel dependen yaitu excess return. Hasil penelitian ini sesuai dengan penelitian Fama and French (1993). Sehingga model Three Factor Fama and French dapat mengestimasi return saham Jakarta Islamic Index (JII) periode 2014-2016.

\section{Hasil Uji Asumsi Klasik}

Uji asumsi klasik digunakan untuk Capital Asset Pricing Model (CAPM). Adapun uji asumsi klasik pada penelitian ini meliputi uji heteroskedatisitas, autokorelasi dan normalitas.. Berikut hasil dari ketiga uji asumsi klasik tersebut.

\section{Uji Heteroskedastisitas}

Uji heteroskedastisitas dalam penelitian ini menggunakan Uji White. Adapun Hasil uji White sebagai berikut. 
Tabel 7. Hasil Uji Heteroskedatisitas

\begin{tabular}{|c|c|c|c|}
\hline F-statistic & 1.008515 & Prob. F(2,16) & 0.3868 \\
\hline Obs*R-squared & 2.127076 & Prob. Chi-Square(2) & 0.3452 \\
\hline Scaled explained SS & 1.033257 & Prob. Chi-Square(2) & 0.5965 \\
\hline
\end{tabular}

Sumber: Diolah Kembali, 2018

Berdasarkan hasil uji heteroskedatisitas diatas bahwa nilai probabilitas obs* $\mathrm{R}$-square sebesar 0,3452 . Artinya penelitian ini bebas dari heteroskedatisitas karena probabilitas obs* $\mathrm{R}-$ square $0,3452>\alpha 0,05$.

\section{Uji Autokorelasi}

Uji autokorelasi yang digunakan dalam penelitian inni adalah uji Dorbin Watson (DW). Berdasarkan tabel 5.14 diatas diketahui bahwa nilai Durbin-watson (DW) sebesar 2.225596. Sehingga dapat disimpulkan bahwa penelitian ini bebas dari autokorelsi karena DW lebih besar dari dL 1,55 dan lebih kecil dari Du 2,46.

\section{Uji Normalitas}

Jumlah sampel penelitian ini kurang dari 30, sehigga diperlukan uji normalitas. Uji normalitas residual dari persamaan regresi menggunakan metode Jarque - Bera. Berikut hasil uji normalitas.

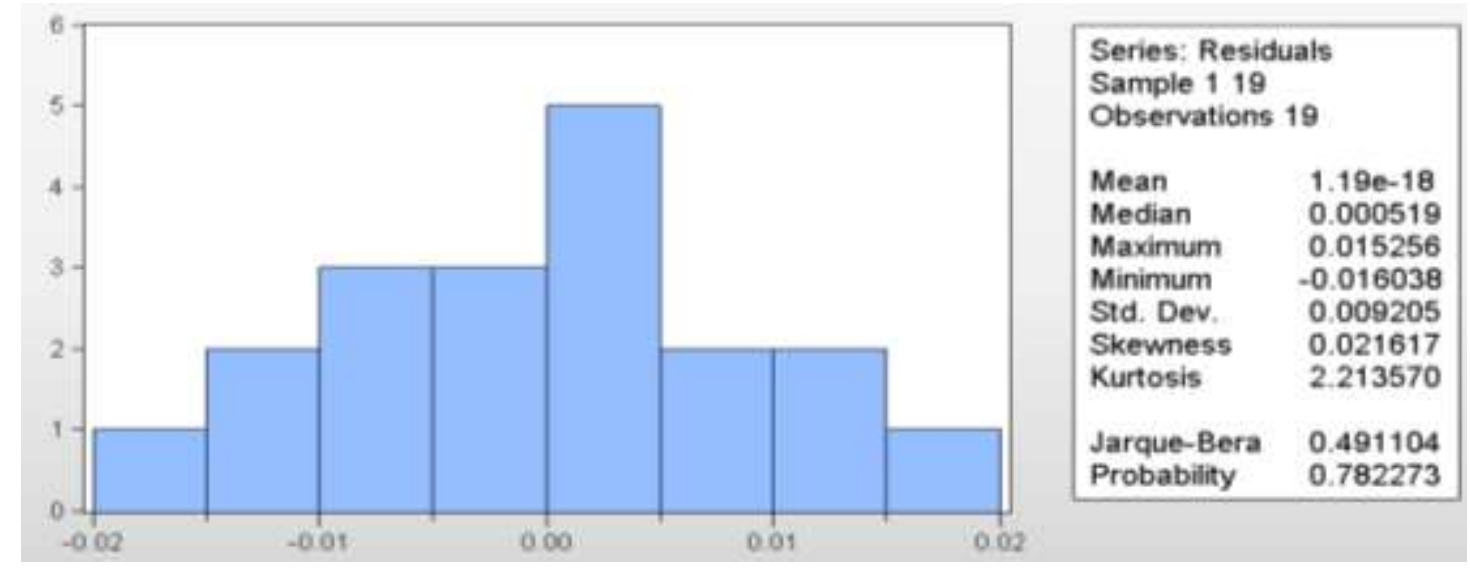

\section{Gambar 1. Hasil uji normalitas}

Berdasarkan gambar diatas dapat disimpulkan bahwa penelitian ini berdistribusi normal karena hasil dari Probability sebesar $0,782273>\alpha 0,05$. Dengam demikian residual dari persamaan regresi berdistribusi normal sehingga sudah memenuhi asumsi normalitas.

\section{Pemilihan Asset Pricing Model dalam Mengestimasi Return}

Pemilihan Asset Pricing Model yang terbaik dari penelitian ini mengikuti kriteria dari penelitian yang dilakukan Porras (1998) dan Bartholdy (2004) yaitu dengan menggunakan koefisien determinasi (Adjusted $\mathrm{R}^{2}$ ). Dibawah ini koefisien determinasi (Adjusted $\mathrm{R} 2$ ) dari kedua Asset Pricing Model.

Tabel 8. Adjusted $\mathbf{R}^{2}$ dari Kedua Asset Pricing Model

\begin{tabular}{|c|c|c|}
\hline No & Asset Pricing Model & ${\text { Adjusted } \boldsymbol{R}^{\mathbf{2}}}$ \\
\hline 1. & Capital Asset Pricing Model (CAPM) & 0,031452 \\
\hline
\end{tabular}




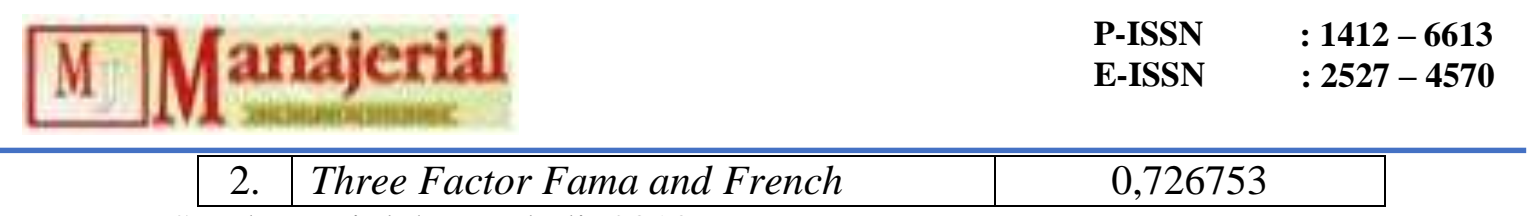

Sumber: Diolah Kembali, 2018

Dilihat dari tabel diatas bahwa Adjusted $R^{2}$ Capital Asset Pricing Model (CAPM) sebesar 0,031452 lebh kecil dibandingkan Three Factor Fama and French sebesar 0,726753. Sehingga Asset Pricing Model yang terbaik dalam mengestimasi Return saham Jakarta Islamic Index (JII) periode 2014-2016 adalah Three Factor Fama and French. Hasil penelitian ini didukung oleh penelitian yang dilakukan oleh Securato, at al dan Bello (2008) bahwa three factors pricing model lebih baik menjelaskan return dibandingkan CAPM.

\section{KESIMPULAN}

Berdasarkan hasil analisis dan pembahsan terkait dengan pemilihan Asset Pricing Model yang terbaik dalam mengestimasi return. Dapat dikemukakan beberapa kesimpulan sebagai berikut:

1. Pada model Capital Asset Pricing Model bahwa beta tidak berpengaruh terhadap return saham Jakarta Islamic Indeks (JII) periode 2014-2016.

2. Pada model Three Factor Fama and French secara parsial market return dan firm size berpengaruh positif terhadap return dengan tingkat signifikansi sempurna sedangkan book to market ratio tidak berpengaruh signifikan terhadap return Jakarta Islamic Indeks (JII) periode 2014-2016. Kemudian secara simultan market return, firm size, dan book to market ratio secara bersama-sama berpengaruh terhadap return Jakarta Islamic Indeks (JII) periode 20142016.

3.Asset Pricing Model yang terbaik dalam mengestimasi Return saham Jakarta Islamic Index (JII) periode 2014-2016 adalah Three Factor Fama and French.

\section{DAFTAR PUSTAKA}

Prabawanti, nisita. (2010). Analisis Komparasi Kinerja Capital Asset Pricing Model, Three Factors Pricing Model, dan Four Factors Pricing Model (Studi Pada Saham Perusahaan Non Keuangan Di Bursa Efek Indonesia). Surakarta : Universitas Sebelas Maret.

Komara, E. F. (2016). Pengujian Validitas Empiris Capital Asset Pricing Model (CAPM) Di Jakarta Islamic Indeks (JII) Periode 2011-2014. Jurnal Ekonomi Manajemen \& Akuntansi, Vol.13, No.2,pp.158-172.

Premananto, G. C., \& Madyan, M. (2004). Perbandingan Keakuratan Capital Asset Pricing Model Dan Arbitrage Pricing Theory Dalam Memprediksi Tingkat Pendapatan Saham Industri Manufaktur Sebelum Dan Semasa Krisis Ekonomi. Jurnal Penelitian Dinamika Sosial, Vol.2, No.5, pp.125-139.

Sudiyatno, B., \& Irsad, M. (2011). Study of The Three Factor Model Fama and French in Indonesia Stock Exchange. Jurnal Bisnis dan Ekonomi (JBE),Vol.18, No.2, pp.126 - 136.

Ismanto, H. (2011). Analisis Pengaruh Perusahaan, Book to Market Value, dan bata Terhadap Return Saham di BEI. Jurnal Ekonomi dan Pendidikan,Vol.8,No.2,pp. 186-205.

Lemiyana. (2015). Analisis Model CAPM dan APT Dalam Memprediksi Tingkat Return Saham Syariah.I-Finance, vol 1, No.1, pp.1-20. 
Isnurhadi. (2014). Analisis Model Capm Dalam Memprediksi Tingkat Return Saham Syariah Dan Konvensional. Jurnal Ilmiah Manajemen Bisnis dan Terapan,No.2.pp.19-31.

Komara, E. F,. (2016). Pengujian Fama And French Three Factor Model Pada Indeks Saham Syariah Indonesia (ISSI) Yang Terdaftar Dalam Daftar Efek Syariah (Des) Dan Tercatat Di Bursa Efek Indonesia (BEI) Periode 2011-2014. Bandung : Universitas Padjajaran. "unpublished".

Simangunsong, Y. M., \& Wirama, D. G. (2014). Pengujian Validitas Empiris Capital Asset Pricing Model Di Pasar Modal Indonesia. Jurnal Akuntansi dan Bisnis, Vol 9, No.1, pp.57-64.

Chui, A. C. W., and Wei, K. C. J. (1998). Book-to-Market, Firm Size, and the Turnof-the-Year Effect: Evidence from Pacific Basin Emerging Markets. Pacific Basin Finance Journal, Vol.6, pp.275-293.

Securato, R. \& Rogers, P. “Comparative Study of CAPM, Fama and French Model, and Reward Beta Approach in The Brazilian Market". Working Paper. University of Sao Paulo, 1-18

Bello, Z. (2008). "A Statistical Comparison Of The Capm To The FamaFrench Three Factor Model And The Cahart's Model'. Global Journal Of Finance And Banking 2 (2), 14-24.

Porras, D. (1998). "The CAPM vs. The Fama and French Three Factors Pricing Model: A Comparison Using Value Line Investment Survey". SRRN Working Paper.

Bartholdy, J. \& Peare, P. (2005). "Estimation of expected return: CAPM vs Fama and French". International Review of Financial Analysis, 14, 407-427.

Jones, C. (2014). Invesment Principles And Concepts, twelfth edition. John wiley \& sons,inc.

Black, F., Jensen, M. C. \& Scholes, M. (1972). The Capital Asset Pricing Model: Some Empirical Tests. Studies in the Theory of Capital Markets, M. C. Jensen edition, Praeger Publishers.

Brav, A., Lehavy, R. \& Michaely R. (2005). Using Expectations to Test Asset Pricing Models. Financial Management, 34 (3), pp: 5-37.

Ross, A, S., Westerfield, R, W., \& Jordan, B, D. (2010). Fundamentals of Corporate Finance, Ninth edition. New York : Mc Graw-Hill.

Lintner, J. (1965). The Valuation of Risk Assets and the Selection of Risky Investment in Stock Portfolio and Capital Budgets, The Review of Economics and Statistics, Vol. 47, No. 1.

Sharpe, W, F. (1964). Capital Asset Prices: A Theory of Market Equilibrium under Conditions of Risk. The Journal of Finance, Vol. 19, No. 3 (Sep., 1964).

Astuti, T. W. (2012). Pengujian Fama and French Three Factor Model Pada Badan Usaha 
Sektor Manufaktur yang Terdaftar di Bursa Efek Indonesia Periode 2008 - 2010. Surabaya: Fakultas Bisnis dan Ekonomika Ubaya.

Fama, E, F., and French, K., R. (1992). The Cross-Section of Expected Stock Return. Journal of Finance, Vol.47, No.2, pp.427-466

Fama, E. F., and French, K., R. (1993). Common Risk Factor in The Return of Stocks and Bonds. Journal of Finance Economics, Vol. 33, pp.3-56.

Subekti, I., \& Kusuma, I. W. (2000). Assosiasi Antara Set Kesempatan Investasi dengan Kebijakan Pendanaan dan Dividen Perusahaan, Serta Implikasinya Pada Perubahan Harga Saham, SNA IV, IAI, hal. 820-845.

Hardianto, d., \& Suherman. (2009). Pengujian Fama-French Three-Factor Model di Indonesia. Jurnal Keuangan dan Perbankan,Vol.13, No.2,pp.18-28.

Irawan, R., \& Murhadi, W, R. (2012). Analisis Pengaruh Three Factor Model dan Persentase Kepemilikan Asing Terhadap Tingkat Return di Bursa Efek Indonesia. Surabaya: Universitas Surabaya.

Sudiyatno, B., \& Irsad, M. (2011). Study of The Three Factor Model Fama and French in Indonesia Stock Exchange. Jurnal Bisnis dan Ekonomi (JBE),Vol.18, No.2, pp.126 - 136.

Nurafiyana, I. (2010). Kemampuan Fama and French Three Factor Model dan Model CAPM Dalam Menjelaskan Return Saham (Studi Kasus Pada JII Periode Januari 2004 Desember 2009. Yogyakarta : Universitas Islam Negeri Sunan Kalijaga.

Malin., M. \& Veeraraghavan, M. (2004). On The Robustness Of The Fama and French Multifactor Model: Evidence From France, Germany and The United Kingdom. International Journal Of Business and Economics, Vol.3, No.2, pp.155-176.

Nofitasari, M. (2018). Analisis Perbandingan Capital Asset Pricing Model dengan Three Factor Pricing Model Dalam Mengestimasi Return Saham. Surakarta : Universitas Muhammadiyah Surakarta.

Pitriyanti, K, M. Dharmawan Komang.Gandhiadi.2015. Perbandingan Capital Asset Pricing Model (CAPM) dan Three Factor Fama and French (TFMFF) Dalam Mengestimasi Return Saham. Vol 4, No.4, pp.181-187.

Rakhmawati, U. (2015). Analisis Fama and French Model dan Asset Pricing Model. Vol.4, No. 8, pp.1-18.

Rizkiana, S., M. (2011). Studi Pembandingan Model Penilaian Aset: Model Tiga Faktor Fama dan French dengan Capital Asset Pricing Model pada Bursa Efek Indonesia. Semarang : Universitas Diponegoro.

www.sahamok.com

www.idx.com 